\title{
Os troféus militares e a memória da guerra na Grécia antiga
}

\author{
Patrícia Boreggio do Valle Pontin*
}

PONTIN, P.B.V. Os troféus militares e a memória da guerra na Grécia antiga. Revista do Museu de Arqueologia e Etnologia, São Paulo, 19: 221-233, 2009.

Resumo: Este trabalho tem por objetivo compreender como o estudo dos troféus militares, na Grécia, desde época arcaica, pode resgatar a presença de um rito militar destinado a eternizar a memória de uma batalha, além de fixar e controlar determinadas energias apotropaicas.

Palavras-chave: Troféu Militar- Guerra - Grécia Antiga - Armamento

\section{O troféu grego}

(...) A vitória sem honra era inaceitável; não podia haver honra sem proclamação pública, e não podia haver publicidade sem a prova que representava o troféu.

(Finley, El mundo de Odiseu, 1986)

0 eixar claro testemunho e memória depois da batalha ganha tem sido uma constante na história da guerra. Porque obter a vitória significava orgulho, prestígio, botim e possivelmente terras. Para os gregos o levantar o troféu no mesmo lugar onde havia se desenvolvido a contenda supunha não só um símbolo tangível da vitória do vencedor, da derrota e fuga do inimigo, como também um rito religioso bem estabelecido (Gabaldón Martínez, 2005: 21).

$\left({ }^{*}\right)$ Museu de Arqueologia e Etnologia. Pós-doutoranda em Arqueologia. Pesquisadora do Laboratório de Estudos sobre a Cidade Antiga labeca. Bolsista FAPESP. <ppontin@usp.br>
O troféu, $\tau \rho o ́ \pi \alpha \imath o v$, por excelência, é, como escreveu Gilbert C. Picard (1957: 13), uma espécie de "manequim" em forma de cruz revestido com armas que lhe dão uma aparência humana. Esse termo tem sido também empregado, tanto pelos autores clássicos como pela recente bibliografia, para falar de amontoamentos de armas, monumentos comemorativos, tumbas em honra aos caídos na guerra, oferendas nos santuários, dedicações de armas (Gabaldón Martínez 2005: 21).

Aqui pretendemos analisar o significado do troféu grego, destacando sempre que o autêntico tropaion é o resultado de um ritual de armas, um a mais dos que se realizariam ao fim das hostilidades.

Seu estudo oferece um amplo leque de possibilidades. Pode-se distinguir o troféu grego do romano e estudar a ampla representação do tema sobre suporte numismático (moedas helênicas, vitorianas, emissões dos imperadores romanos), pictórico e vascular. O termo tropaion aparece possivelmente pela primeira vez na primeira metade do século V a.C. São Tucídides e Xenofonte quem com mais frequência se referem ao troféu; Tucídides o faz em cinquenta e cinco ocasiões e Xenofonte em suas Helênicas 
menciona-o umas trinta vezes (Pritchett 1974: 264-267). Há também muitas referências a ele na obra de Pausânias que fala de monumentos em cidades e lugares de culto, como em Olímpia e Argos (Pausânias, V, 27, 11 e II, 20,1), e, sobretudo, de troféus comemorativos construídos em pedra que possivelmente pode ver durante suas viagens pela Grécia no século II a.C. (Pausânias, I, 32,5 (Maratona); I, 36,1 (Salamina); IX, 2, 6 (Platéia); II, 21,8 (Argos)) (Gabaldón Martínez 2005: 21-22).

$O$ vestígio arqueológico é mais evidente no caso dos "troféus permanentes", autênticos monumentos feitos de pedra. Os restos mais antigos deste tipo de troféus pertencem às construções comemorativas que se erigiram durante as Guerras Persas, provavelmente após as grandes batalhas, Maratona, Platéia e Salamina (Gabaldón Martínez 2005: 15). Levantaram primeiro autênticos tropaia com armas ou despojos, que posteriormente, depois de vários anos, foram substituídos por outros de pedra, convertendo-se em monumentos comemorativos, em "troféus permanentes" (West III 1969: 17-19).

\section{O troféu: uma breve revisão historiográfica}

Um trabalho dos mais relevantes é o artigo de Karl Woelcke, Beiträge zur Geschichte des Tropaions, publicado em 1911. Este autor destacou a origem grega do monumento, definiu suas características e distinguiu os dois tipos de troféus. Aqueles levantados no campo de batalha com as próprias armas dos vencidos e os construídos em pedra ou em bronze, que aqui chamaremos de "troféus permanentes". Woelcke recolheu também um conjunto muito útil de manifestações artísticas tanto gregas como romanas, desde vasos de figuras vermelhas até o friso superior do mausoléu de Cecília Metela, assim como uma completa mostra de moedas com a representação do tema (Gabaldón Martínez 2005: 22-23).

Dois anos depois da publicação de Woelcke, M.A. Reinach escreveu "Les trophées et les origines religieuses de la guerre", um artigo que curiosamente não foi muito citado na bibliogra- fia posterior e que, contudo, expõe ideias interessantes. Aqui Reinach centra-se nas origens profundas da guerra e sua relação com o religioso. O troféu seria uma consagração parcial; além disso, podiam distinguir-se dois tipos: o troféu tumuliforme e o antropomorfo. $\mathrm{O}$ primeiro seria mais tardio e mais frequente entre os romanos (Gabaldón Martínez 2005: 23, nota 62). Trata-se de um amontoamento de armas onde dominam os escudos. O segundo, o que consideramos o troféu por excelência, é para Reinach um "guerreiro artificial", vestido com a panóplia do vencido. O original de sua interpretação está em que, para ele, o troféu tumuliforme representaria o resultado vitorioso de uma batalha, na qual muitos participariam, enquanto um troféu com forma humana recordaria um duelo, uma espécie de combate singular em cujo desenlace o vencedor constrói o troféu com as armas de seu oponente. Por isso, este autor lhe dá uma origem primitiva (Reinach 1913: 230).

Em 1955 foi publicado um livro na Polônia intitulado Geneza Tropaionu. Sua autora, Zofia Gansiniec, pôs o acento na relação do troféu com o Paládio e no mito de Tarpéia. (Lenda da jovem Tarpéia que morre sepultada pelo ouro e os escudos. Plutarco, Rômulo, XVII, 4; Plutarco, Moralia 309 C; Dionísio de Halicarnaso (II, 40, 1-2); Propércio, Elegias IV, 4) Na opinião de Gabaldón Martínez (2005: 23), Gansiniec explica de forma muito clara como o significado votivo do originário troféu grego, o tronco coberto de armas ensanguentadas, pouco a pouco se converte em algo secundário, enquanto seu caráter simbólico como monumento de vitória (o que chamamos troféu permanente) passa a um primeiro plano (Gansiniec 1955: 141).

Em 1957 apareceram dois livros importantes no estudo do troféu. Por um lado, Andréas Jozef Janssen publicou Het antieke Tropaion, com resumo em inglês e ampla bibliografia sobre o tema. Por outro, G.C. Picard publicou sua obra Les trophées romains, com um primeiro capítulo dedicado ao troféu grego. Janssen insiste no significado da palavra $\tau \rho o ́ \pi \alpha \iota v$, sua derivação de $\tau \rho o \pi \eta ́$, ação de dar a volta, giro, seu uso nos textos e a amplitude de significados. Assim, um troféu pode ser uma estátua, 
um edifício, um prêmio etc. Também desenvolveu a teoria de que os vocábulos compostos com o termo tropaion apontam a uma origem do troféu antropomorfo e não tumular. Para ele seria a representação simbólica do oponente vencido na batalha. A obra de Janssen é talvez a melhor no que se refere à evolução do tema do troféu na arte antiga; e dado que não há testemunhos arqueológicos de tropaia no autêntico sentido da palavra, a análise de sua representação plástica é necessária, já que o tropaion ou tropaeum, sobretudo na arte romana, chegará a ser um elemento iconográfico muito empregado na arquitetura triunfal (Gabaldón Martínez 2005: 23-24, nota 66; Woelcke 1911; Janssen 1957; Picard 1957; Conti 2001).

Por outro lado, Picard atribuiu ao troféu grego, ao originário, conotações mágicas e apotropaicas. Nele ficariam neutralizadas as forças hostis liberadas na batalha (Picard 1957: 13, 27-28). Este valor catártico e mágico explicaria o silêncio dos autores anteriores ao século VI a.C. (Picard 1957: 32). Esta teoria não chega a convencer alguns pesquisadores (Lonis 1979: 135; Pritchett 1974: 247-248). Contudo, a evolução do troféu que estabelece este autor é, em nossa opinião, muito acertada. Outros autores como Gabaldón Martínez (2005: 24) e Salcedo (1983: 277-278) também a consideram acertada.

Nos anos setenta do século passado William K. Pritchett inicia sua série The Greek State at War, dedicando parte do segundo volume ao troféu grego. Este investigador recolhe as diferentes teorias desenvolvidas até o momento e analisa de maneira muito ordenada as características do troféu sempre com base nas fontes textuais antigas. Pritchett considera que a presença do troféu, ainda que não se utilize o termo, é segura já no mundo homérico. Para ele, o tropaion era uma dedicação a um deus a quem se atribuísse a vitória, estava protegido por uma sanção divina e se respeitava, inclusive levantado em território inimigo. Em 1979 publicou-se a terceira parte da série, destinada aos aspectos religiosos, onde volta a tratar do troféu e dos rituais em torno da vitória, como a dedicação dos despojos inimigos (Gabaldón Martínez 2005: 24).
Também em 1979, Raoul Lonis publica Guerre et Religion en Gréce à l'Époque Classique, obra de referência para o estudo dos rituais da guerra. A tese de Lonis é distinta das anteriores. Para ele, o troféu não corresponde a um rito propiciatório, nem de ação de graças, senão de julgamento, isto é, ele é a representação do deus, Zeus Tropaios, que é testemunha do combate, como se se tratasse de uma competição, o agon, que necessita de um árbitro, um juiz que marque e garanta a vitória. $\mathrm{O}$ tropaion é, nas palavras do autor: "a estátua do deus, garantia da vitória, árbitro supremo da confrontação" (Lonis 1979: 139). Esta ideia do combate agonístico se relaciona com a ideia de que o troféu é, antes de tudo, um símbolo material da vitória. Em 1985 Lonis realizou uma revisão historiográfica muito útil da guerra na Grécia Antiga na qual o troféu também é considerado (Lonis 1985: 373).

Um dos trabalhos mais recentes sobre o tema, fundamentalmente do troféu romano, é o intitulado Da albero-trofeo a trofeo-croce, de Graziella Conti (2001). Neste mais que completo estudo realiza-se um percurso por sua evolução desde seu caráter puramente antropomorfo, esse tronco revestido de armas, à sua representação como uma espécie de cruz (Cook 1965: 601-605) no começo do cristianismo. Para a autora deste trabalho o troféu é sempre um elemento polissêmico, cujo significado pode variar segundo o emprego que se faça dele (Conti 2001: 319).

Na obra de F.J. Fernández Nieto, Los acuerdos bélicos en la antigua Grecia, o autor fala do troféu em termos jurídicos. Para este autor "seu caráter jurídico provém de um costume de direito aceito por todos os gregos; ele é a marca do triunfo e, ao mesmo tempo, o limite (geográfico e simbólico) que os vencedores impõem aos vencidos proibindo-lhes ir mais além sob a pena de incorrer no pecado da hybris" (Fernández Nieto 1975: 111).

Por outro lado, uma obra valiosa em relação a uma definição do conceito do troféu grego é o livro de Pierre Ducrey (1985), Guerre et guerriers dans la Grèce antique, apesar de ser uma obra de caráter mais de difusão científica que as anteriores. Também, na obra de Michael 
Sage (1996) recolhe-se uma seleção das fontes textuais de cada um dos aspectos inerentes ao modo grego de fazer a guerra, entre eles o troféu.

Em um interessante e revolucionário trabalho de um grande perito na guerra dos hoplitas, Krentz (2002), analisa-se a origem do troféu grego, sendo este para o autor não anterior a meados de século $\mathrm{V}$ a.C. (Krentz 2002: 32), como muitos outros elementos que formam parte do agon hoplita.

Finalmente, sobre o troféu como ritual de vitória em que as armas estão envolvidas temos o excelente trabalho de María del Mar Gabaldón Matínez (2005). Em um apartado de seu estudo a autora analisa a presença de armas e outros objetos relacionados com o equipamento militar nos santuários gregos e seu vínculo com os ritos de vitória, em especial a construção de troféus no campo de batalha.

\section{Troféu, vitória e religião}

O troféu construía-se pendurando a vestimenta e as armas, geralmente elmo, escudo e lança, do derrotado, a um tronco cortado de alguma árvore das cercanias (Zanker 1992: 272, fig. 182; Touchette 1998: 327); junto a ele somente colocava-se uma inscrição comemorativa em uma tábua ou nas armas, normalmente no escudo. Seguramente, na construção do troféu, seriam utilizadas armas valiosas, seja pela identidade de seu possuidor, seja pelas próprias características formais das armas (Segarra 1997: 30), talvez escolhidas entre as melhores das capturadas depois do despojo dos inimigos caídos, possivelmente, as de um chefe (Tucidides, IV, 12, 1; Pausânias IV, 32, 5-6). Antes de construir o troféu os vencidos podiam retirar seus mortos sob trégua (spondai) (Burkert 1993: 154-155). Em princípio, o objetivo da guerra no mundo grego antigo não era a aniquilação do inimigo, senão a posse do terreno. Depois o troféu podia ser levantado imediatamente ou em pouco tempo (Plutarco, Timoleonte, XXIX). Por sua parte, o exército derrotado estava obrigado a respeitar o tropaion de seu inimigo, ainda que isso significasse tolerar a presença de um monumento comemo- rativo da própria derrota, inclusive nas portas da própria cidade. Contudo, o troféu era construído somente de materiais perecíveis e com o passar do tempo desmoronava, o que fazia possível esquecer as hostilidades passadas (Gabaldón Martínez 2005: 27-28).

O certo é que construir um tropaion no campo de batalha tinha certo valor psicológico; era toda uma honra que enchia de orgulho os vencedores dispostos a participar de outra contenda, porém fundamentalmente era um dever religioso (Plutarco, Cimon e Luculo, III; Plutarco, Péricles, XXXVIII; Gabaldón Martínez 2005: 28, nota 87).

O fato de o troféu ser construído com as armas inimigas poderia nos fazer pensar na possibilidade de que personificasse o vencido (Burkert 1983: 66) e não o vencedor. Contudo, a ideia de que é uma representação de um deus tem sido a mais aceita por alguns autores (Gansiniec 1955: 141; Picard 1957: 13; Lonis 1979: 139; Burkert 1985: 128), baseando-se na menção de Zeus Tropaios, como deus da vitória, nas fontes antigas (Pausânias, I, 36, 1 e III, 12,9). Por outro lado, não há que se duvidar de que os gregos davam a aparência humana a seus deuses. Nesta linha, para Picard (1957: 13, $24,26)$ o troféu não é outra coisa senão uma estátua de uma divindade armada, análoga aos Palladia, estátuas nas quais reside o sagrado (Gabaldón Martínez 2005: 28).

$\mathrm{Na}$ representação do troféu na arte grega não é comum encontrar o tema do cativo ou do derrotado. Contudo, na maior parte dos exemplos romanos, tanto em moedas como em relevo, aparece a figura do vencido desarmado lamentando-se sobre os despojos ou sob o tropaeum. Isto pode indicar que ele não é a representação de um vencido, mas sim uma espécie de força que "arrebatou" suas armas e poder (Gabaldón Martínez, 2005: 28).

O troféu pode ser uma representação simbólica de um deus ou, melhor, um receptáculo da divindade (talvez de maneira temporal), porém não acreditamos que se trate de uma estátua de culto permanente já que, dependendo das batalhas, ele podia ser levantado em lugares bastante distantes da terra pátria, inclusive em solo inimigo. Sua vigência duraria 
enquanto continuassem as hostilidades com seus rituais, ainda que por seu caráter divino não pudesse ser derrubado. É a esse deus, presente na contenda, ao qual se dedicava a vitória e por isso o fato de erigir um troféu é, na nossa opinião, assim como na opinião de Gabaldón Martinez (2005: 28), uma dedicação.

Também destacamos que nenhum dos deuses do panteão grego era um estranho na guerra. A vitória podia ser oferecida a Posidão depois de uma batalha naval (Tucídides, II, 84, 4; Pausânias, VIII, 10, 9) ou a vários deuses por sua vez, como faz o romano Sila ao construir os troféus de Queronéia (Plutarco, Sila, XIX, 9, 10). Héracles é outra deidade relacionada com o troféu, como figura nas moedas de Heracléa de Bitínia, em cujos reversos o herói os constrói com um martelo (Woelcke 1911: 206). Contudo, o deus mais relacionado com o troféu é Zeus, por excelência o $\tau \rho o \pi \alpha \dddot{i o s}$, $\tau \rho о \pi \alpha \iota \ddot{\chi \chi} о \varsigma, \tau \rho о \pi \alpha \iota \ddot{v} \chi о \varsigma$ o portador da vitória (Launey 1987: 940).

A divindade que mais acompanha o troféu, nas imagens, é Nike, a deusa alada, verdadeira personificação da Vitória (Sófocles, Traquinias, 751), que veremos representada em vários suportes desde o século V a.C. "esculpindo-o", levando-o nos ombros ou coroando-o (Gabaldón 1997: 38-40, figs. 1-3). Destacamos a peliké de figuras vermelhas do Museu de Boston, obra do chamado "Pintor do troféu" (Caskey e Beazley 1963: 65-66), no qual a deusa se encontra preparando o troféu; com um prego parece ajustar o elmo coríntio do "manequim" (Caskey e Beazley 1963: 66-67) (Fig. 1).

Nike não aparece só relacionada com o troféu; é frequente vê-la em cenas de sacrifícios, entregando as armas ao guerreiro, em libações etc. Para Lonis (1979: 231) se Zeus é o árbitro, o que sanciona a vitória, a deusa é sua mensageira.

\section{As origens do troféu grego}

Sobre a ausência da palavra tropaion nos textos anteriores ao século $\mathrm{V}$ a.C. H. Bowden (1990: 115-116) sugere três possíveis explicações: 1) utilizava-se a palavra em linguagem oral, porém não aparece na literatura; 2) os

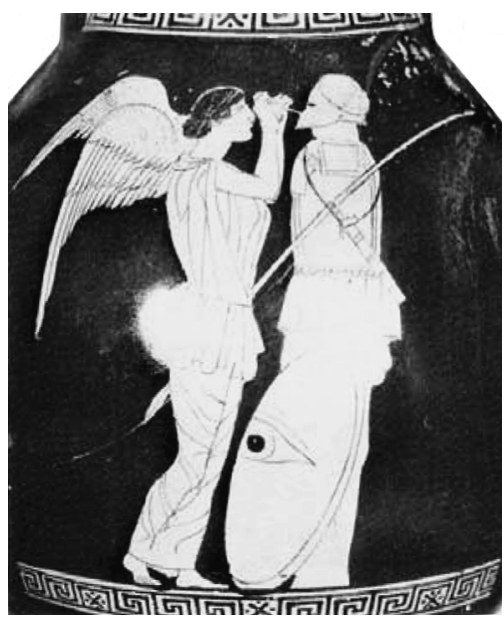

Fig. 1. Tropaion: a deusa alada da vitória, Niké, fixa as armas capturadas em um tronco de árvore, em uma das mais antigas representações do troféu no campo de batalha. Pélike de figuras vermelhas do "Pintor do troféu”, c. 450 a.C. Museum of Fine Arts, Boston. (Fonte: Van Wees 2004, fig. XIII).

troféus não começam a ser construídos até o século V a.C.; 3) os troféus existiam antes do século $\mathrm{V}$ a.C., porém não eram chamados tropaia.

Segundo Bowden a primeira explicação não é muito provável, já que na literatura de época arcaica a guerra é um dos temas principais, e os troféus tenderiam a aparecer. A respeito da segunda explicação, a que vincula o troféu com a guerra hoplita de época clássica (a explicação que sugerem Lonis 1979 e Krentz 2002), tem que se apresentar uma objeção: o termo tropaion (nos textos do século V a.C.) não só faz alusão ao manequim levantado no campo de batalha, como também às vezes das oferendas de armas nos santuários (Sófocles, Traquinias, 751), e as dedicações de armamento (especialmente os despojos inimigos) nos lugares de culto existiam já na épica homérica. A consagração de armas nos templos não é certamente igual à de um troféu construído no campo de batalha, porém têm muito a ver (ambas são dedicações), tanto que na literatura clássica utiliza-se a palavra tropaion para referir-se a uma coisa e também para a outra. Ainda que a definição mais correta do troféu grego seja a de um tronco ou árvore vestido 
com os despojos inimigos e construído no lugar onde se desenvolveu a contenda (Gabaldón Martínez, 2005: 31).

A respeito da terceira explicação, $\mathrm{H}$. Bowden considera que é a mais acertada. Para este autor, o troféu na origem é um marcador, um elemento que assinala o território onde se obteve a vitória. A relação entre território e a guerra em época arcaica foi assinalada por Polignac (1984 e 1995). Portanto, segundo Bowden, o troféu tinha em suas origens um significado como horos (őpos), isto é, um indicador do território conquistado (Bowden 1990: 116). Portanto é provável que no período arcaico se utilizasse um termo (que desconhecemos, talvez horos) fazendo alusão ao caráter do troféu como marcador e a partir do século $\mathrm{V}$ a.C. se empregasse a palavra $\tau \rho o ́ \pi \alpha \imath o v$ em alusão a seu destacado vínculo com Zeus Tropaios, o deus que dá um giro na batalha (Sófocles, Traquinias, 303). Concordamos com Bowden em que suas origens podem ser buscadas antes do século $\mathrm{V}$ a.C. frente à ausência do termo tropaion nas fontes literárias, e certamente estamos de acordo em que o troféu é um marcador de território, porém não acreditamos que esta característica desaparecera com o tempo, frente aos meios de fazer a guerra (Gabaldón Martínez 2005: 31-32).

Por outro lado, e voltando às suas origens, tem que se destacar que no mundo homérico o arrebatar as armas do inimigo caído era um dos primeiros atos que ratificavam a vitória (Heródoto, I, 82, 5; Tucídides, IV, 44; Fernández Nieto 1975: 110; Connor 1988: 15, 25).

Em uma direção contrária, Peter Krentz assinalou recentemente que a origem do troféu, como as armas capturadas penduradas em um poste ou árvore, não deve ser anterior a meados do século V a.C. (Krentz, 2002: 32). O autor considera que os troféus construídos imediatamente depois da contenda com materiais perecíveis são posteriores aos monumentos “permanentes" das Guerras Persas. Além disso, assinala que no geral as regras que configuram o tipo de guerra ritualizada dos hoplitas (agon), como podem ser cantar o pean ou construir o troféu, não surgiram antes da primeira metade do século V a.C. Deste modo, na opinião de
Krentz (2002), os gregos de época arcaica lutavam seguindo os convencionalismos da épica homérica, enquanto o agon hoplita foi inventado no século V a.C. Contudo, tal e qual pensamos, ainda que no século VIII a.C. não existisse a falange hoplita havia nos tempos de Homero uma série de rituais e de regras que davam à guerra uma aparência agonal, a partir da qual se desenvolverá o agon hoplita, provavelmente já presente nos séculos VII a.C. e VI a.C. (Gabaldón Martínez 2005: 32-33).

O estudo dos troféus na Grécia, seu sentido original e sua evolução devem ser entendidos em função da teologia militar. Segundo Romilly (1968: 207-220), tanto a guerra quanto a paz entre as poleis eram cercadas de formalidades, de costumes sagrados de certa forma. A paz era marcada por libações e juramentos em nome das divindades mais importantes. Para os cidadãos das poleis envolvidas, assim como para o restante da Hélade, a paz era assinada pela existência de estelas de pedra, colocadas não só nas respectivas cidades, mas nos principais santuários pan-helênicos, como Delfos e Olímpia. A guerra, por sua vez, segundo a autora (1968: 212), também era cercada de formalidades oficiais, destinadas a estabelecer, diante dos olhos dos deuses e da comunidade, o bom direito do atacante. As convenções dos adversários, a escolha de um "campo fechado", a ereção de um troféu, segundo Detienne (1968: 123), são algumas das regras essenciais do combate guerreiro.

De fato, a guerra assemelhava-se a uma grande ação sacrificial. Depois da batalha, o vencedor ergue um tropáion no local onde esta teve a sua "inflexão" final: as armas dos despojos, armaduras, elmos, escudos e lanças são pendurados num tronco de árvore. Para Burkert (1993: 509-510), isto correspondia ao costume do caçador de pendurar numa árvore a pele, o crânio e a armadura da sua presa.

As estátuas armadas remontam à época minóico-micênica, onde seu testemunho é confirmado por múltiplos monumentos onde vemos o troféu honrado exatamente como uma estátua, por sacrifícios, libações, coroas. Em um anel proveniente de Micenas, que representa uma procissão em honra de uma deusa cujo 
trono se encontra na árvore sagrada, é visível, em segundo plano, por cima, uma pequena figura coberta por um escudo em oito (Nilsson 1967:1). Muito curiosa é a "divindade do escudo”, proveniente de Micenas, pintada com a forma de um escudo grande em forma de oito, por detrás de cujos pés e mãos aparece uma cabeça (Nilsson 1950: 406-12). Havia um número considerável de pequenas estatuetas de bronze de um "deus guerreiro" de proveniência sírio-hitita que vieram para a Grécia, com capacete, escudo e uma lança que brande ameaçadoramente (Burkert 1993: 190-191).

Em sua origem, o troféu era destinado a eternizar a lembrança de uma batalha, não se tratava de um monumento comemorativo. Uma lei religiosa, segundo Diodoro (XIII, 24, 5), que permaneceu em vigor até o final do século $\mathrm{V}$ a.C. prescrevia que este não fosse construído de materiais que não fossem perecíveis.

Os monumentos comemorativos, por sua vez, visavam distinguir-se pela beleza e originalidade de suas formas e de sua decoração, esforçando-se no geral em representar ou sugerir as particularidades de uma vitória da qual o monumento seria a lembrança. Para este fim, os gregos utilizavam as oferendas que faziam nos santuários, eles se serviam do butim para construir os edifícios, templos ou tesouros. Para confeccionar os objetos de arte ou as estátuas utilizavam os materiais mais preciosos. O troféu, ao contrário, conserva por muito tempo seu aspecto severo, fixado pela tradição (Picard 1957: 17).

A maior parte dos autores está de acordo em considerar sua construção como um rito. K. Woelcke (1911: 138-139), por exemplo, o define como uma oferenda de armas feita sobre o local do combate dedicada a um deus que ajudou os combatentes na vitória. A dedicação de armas deduzidas do butim, aos deuses, é um rito comum a todos os povos, ao passo que a ereção do troféu é um rito próprio dos gregos.

Os troféus votivos aparecem nos santuários tardiamente, e eram em primeiro lugar a reprodução dos troféus reais erigidos sobre o campo de batalha (Picard 1957: 17-18). Certos povos, no lugar de dedicar o butim nos tem- plos, preferiam abandonar sobre o campo de batalha as armas penduradas nas árvores, ou acumuladas em montes (Picard 1957: 19). Muitos autores vêem aí sua origem. As armas dos vencidos são carregadas de um "sagrado" que lhes confere um uso perigoso. Portanto é conveniente que as abandonem a uma lenta destruição. Em épocas posteriores, os vencedores desejavam recuperar pelo menos a maior parte das armas. Woelcke mostra que nos poemas homéricos a reutilização das armas conquistadas era a regra, a dedicação ao deus a exceção.

Nesses manequins residia um "sagrado" ou temível, ao qual toda sorte de atenções era necessária. A equivalência entre Tрó $\pi \alpha$ เos e

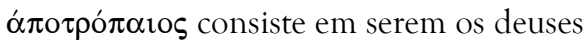
apotropaicos ao mesmo tempo os deuses armados, os deuses da guerra. Eles repelem por sua vez as influências nefastas e os inimigos. $\mathrm{Na}$ concepção primitiva da guerra, os inimigos humanos são menos temíveis que as forças divinas ou demoníacas que se desencadeiam ao seu lado. Essas são as forças que os tropaioi vão combater. Eles são uma espécie de estátua mágica que encerra o Théos Tropáios, um "sagrado" geralmente identificado a Zeus (Picard 1957: 24). O tropáion era uma "imagem de Zeus”, o senhor da vitória.

Podemos dizer que o tropáion designa o fetiche, o objeto no qual se materializa a força apotropaica e geradora da derrota, que se personaliza no Théos Tropáios. É normal que esse fetiche seja coberto de armas, umas consagradas no avanço, outras recolhidas no campo de batalha (Picard 1957: 26).

À primeira vista, segundo Picard (1957: 27), ergue-se um manequim-estátua após o combate, a título de ação de graças: o grego do século $\mathrm{V}$ a.C. que construía o troféu, coroava-o, cantava junto a ele o pean, que era o hino cultual de Apolo. Enfim, representava a estátua de um deus superior. Ele era, em sua origem, uma satisfação dada aos espíritos perversos, ao mesmo tempo em que um meio mágico de os imobilizar. Uma das mais antigas menções literárias ao troféu e sua concepção "mágica" aparece em Ésquilo, nos Sete contra Tebas (v, 954-6) "O troféu é levantado na porta, lá onde 
eles estão caídos; e o demônio, tendo vencido os dois, repousa". Nas fontes materiais, de acordo com Picard (1957: 28), encontramos a lembrança do valor primitivo dele em um grupo de três réplicas helenísticas existentes no Vaticano, no Louvre e em Leptis Magna, que figura uma Niké semi-nua, encostada em um troféu, que levanta a máscara da Górgona que recobria sua face (Picard 1957: 29, nota 1 ). O simbolismo desse monumento reforça ainda mais a sobrevivência do valor mágico do troféu, em que a deusa durante o combate, manifestase sob a forma de um gênio apavorante. A vitória conquistada, ela muda de natureza, torna-se benéfica e apaziguadora. Esse apaziguamento é adquirido precisamente pela ereção do troféu que fixa os miasmas da batalha.

Muitos rituais tinham essa função de fixação e controle de energias, daimonia, que poderiam tornar-se perigosas. Entre os gregos é necessário, por exemplo, enterrar o morto de acordo com rituais determinados para que sua "alma" não vague solta pelo mundo fazendo o mal para os vivos (Kurtz e Boardman 1971). A mesma crença está por trás do costume de erigir um troféu sobre o túmulo, usando as armas do defunto. Este era destinado a acolher sua alma, e a ele fornecer um suporte, substituindo assim, o corpo que este já não possuía (Picard 1957: 30).

Esses troféus funerários tinham a mesma forma e função que os troféus de batalha, pois como estes, imobilizavam os espíritos perigosos. Inversamente, segundo Picard (1957: 32), sua ereção poderia servir também, não só para imobilizar um espírito, mas ao contrário, para evocá-lo em caso de necessidade. Neste caso, ele poderia evocar o espírito de um héroi combatente para cooperar em uma batalha.

Segundo Picard (1957: 35), ao papel apotropaico que representa o prolongamento em época clássica do antigo uso mágico do troféu, acrescenta-se por volta do século V a.C. um papel racional; sua ereção ganha um caráter jurídico. Ele é a marca do sucesso, e ao mesmo tempo um marco material e moral: no lugar onde é erguido o trópaion, a perseguição às linhas inimigas termina. Os vencidos reconhecem sua derrota e pedem autorização para enterrar seus mortos. Os vencedores, por sua vez, os constroem de material perecível não mais para que sua lenta destruição aniquilasse as forças terríveis que ele continha, mas para evitar eternizar a memória do rancor a que ele remetia.

Uma inovação na arte grega muda o valor do troféu no fim do século $V$ a.C. A arte triunfal é uma arte simbólica, tendo a finalidade de proclamar as virtudes do vencedor e seu poder. Não existiam em nenhuma parte da Hélade monumentos comemorando as vitórias; os troféus não eram monumenta propriamente ditos, e não tinham por destinação conservar a lembrança de uma vitória, mas somente proteger os vencedores contra as perigosas consequências de seu próprio sucesso (Picard 1957:36). As coisas mudaram profundamente com a guerra do Peloponeso (431 - 404 a.C.). Desde Homero, os gregos ainda consideravam a vitória como um dom dos deuses, mas até o final do século $\mathrm{V}$ a.C. eles recusavam admitir que certos homens ou mesmo certas coletividades pudessem ser naturalmente predispostos a receber esse favor (Picard 1957: 37).

Os troféus tornam-se simbólicos. A partir do final do século $\mathrm{V}$ a.C. vemos estes multiplicarem-se para lembrar a vitória, ou com a intenção de propiciá-la. Entre seus empregos simbólicos podemos citar o troféu em santuários. Como os tesouros, dedicados nos santuários pan-helênicos, materializam o reconhecimento dos vencedores à atenção de uma divindade, os troféus dedicados nos santuários passam agora a simbolizar a memória de uma vitória. Nos troféus funerários a ideia primitiva era de fixar o morto sobre a tumba, para torná-lo inofensivo. Agora, passa a ser o desejo de eternizar sua "virtude" representada pelo manequim armado.

A teologia oficial de época helenística, imitada pela do Império Romano, definirá o príncipe como um ser de essência sobre-humana (Picard 1957: 39). Essa concepção é indispensável para manter qualquer coesão dentro dos exércitos mercenários depois do século IV a.C.

Inspirada pelos atos religiosos a arte triunfal grega expressa essas ideias na coroação do vencedor e, ereção do culto ao troféu: símbolo da vitória, fortuna, força sobrenatural concedida pelos deuses a certos homens, carisma do chefe. 
O troféu helenístico no século IV a.C. que passa a ter caráter pessoal, durável e monumental, e que simboliza o gênio do chefe, se multiplica nos santuários, sobre as tumbas e monumentos diversos, e até sobre os instrumentos e as jóias de uso privado (Picard 1957: 42).

Sobre o campo de batalha torna-se um monumento durável. Segundo Plutarco (Alc. 207d), em 405, os efésios erigiram um troféu de bronze para comemorar o sucesso sobre os atenienses. Desde o final do século V a.C. foi introduzido o uso dos troféus feitos de materiais preciosos, portanto preparados antecipadamente para serem exibidos no momento da vitória. Os príncipes ou os generais podiam apresentar alguns deles, que já tinham feito vir secretamente, como as imagens "achiropoiètes" trazidas do céu miraculosamente pelo ministério de uma Niké. O troféu, agora construído para ser o mais durável e monumental quanto possivel sobre o campo de batalha, torna-se um amuleto.

O troféu monumental, feito de materiais preciosos, não podia permanecer isolado sem proteção. Este terreno sagrado toma agora o caráter de um verdadeiro téménos. Segundo Picard (1957: 45), os troféus monumentais são analogias dos mausoléus.

Em meados do século IV a.C., segundo Krentz (2002: 32), o troféu aparece sobre as moedas, as gemas, figuras de terracota e esculturas em relevo (Fig. 2).

Em sua origem, as cerimônias celebradas diante do troféu tinham por finalidade fixar e apaziguar o espírito que a ele estava preso. $\mathrm{Na}$ concepção helenística, elas serviam, ao contrário, para renovar a energia vitoriosa do deus cujo troféu é a imagem e a sede.

Eles eternizavam a memória de uma batalha, purificavam os vencedores e eram um marco jurídico e moral da vitória. Dedicados nos santuários os troféus simbolizam a memória de uma vitória, preservando-a, assim como as virtudes e o poder do vencedor.

\section{O troféu e o combate individual}

A palavra tropaion está relacionada com trope, giro, volta (Pritchett 1974: 252). Assim, o

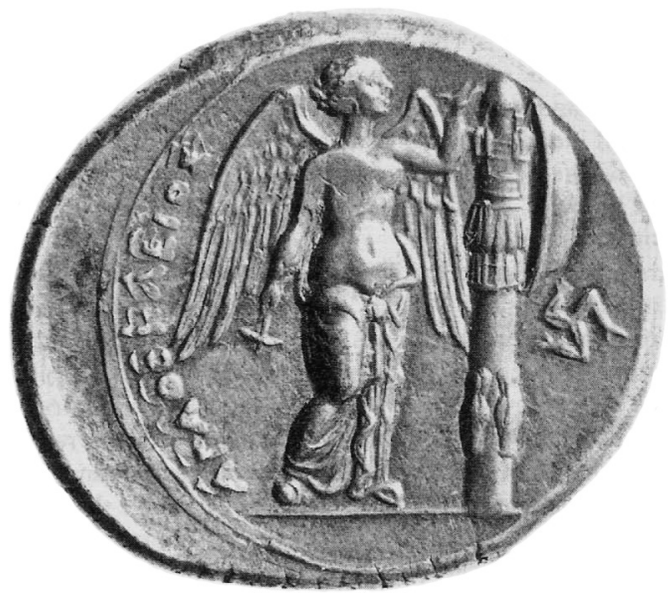

Fig. 2. Moeda de prata feita para comemorar a vitória de Agátocles sobre os cartagineses. No reverso aparece Niké vestida da cintura pra baixo, erigindo um troféu, segurando um prego na mão esquerda e um martelo na direita (Siracusa, Agátocles, 317- 289 a.C. Tetradracma). (Fonte: Chaniotis 2005, 234, fig. 11.1).

troféu se levantaria onde os fatos mudassem, como na fuga dos inimigos. W. R. Connor (1988: 14) assinalou que esse giro corresponde a uma ruptura das filas, a uma transformação do combate coletivo e anônimo na luta pessoal, "corpo a corpo". Sem dúvida, a forma de luta hoplita baseada na falange, não excluía o papel individual do guerreiro. E ainda que a eficácia da falange fundamente-se na coesão do coletivo, não é menos certo que este coletivo esteja formado por uma soma de indivíduos, e que na vitória a glória obtida é a da cidade, porém também a de cada um dos combatentes individuais que orgulhosos lutaram na falange e podiam, portanto, ver no tropaion um símbolo de orgulho tanto pessoal como coletivo (Gabaldón Martínez 2005: 33).

\section{O troféu como dedicação e comemoração da vitória}

Como mencionamos, o troféu é outra forma de dedicação das armas inimigas e, ao mesmo tempo, converte-se no deus que preside um espaço sagrado. O campo de batalha era uma sorte de lugar de culto, a antessala do 
santuário, também presidido por uma divindade, a qual se levará um dízimo (dékaté), a melhor parte ou as primícias do butim (Pritchett 1971: 93-100), ficando uma representação do mesmo no terreno do enfrentamento. Ambas as formas de dedicação são rituais de armas relacionados com a vitória. O lugar onde se desenvolvia a contenda devia ter uma forte carga simbólica porque era ali onde os combatentes se enfrentavam até a morte (Gabaldón Martínez 2005: 30).

A atmosfera que reinava no exército no momento da vitória devia estar muito vinculada com o religioso, sem dúvida a propaganda favorável para o vencedor e os benefícios econômicos materializados no butim (Launey 1987: 902). A própria aquisição de armas no campo de batalha, além de ser algo simbólico, tinha muitas vezes um valor prático. Os despojos não destinados à divindade, o troféu ou as oferendas nos santuários, podiam ser vendidos ou guardados para empregar-se no futuro (Hanson 1989: 204; Van Wees 1996: 56). Segundo as fontes escritas, os espartanos não tinham por costume levar os despojos de guerra aos santuários, porque consideravam que se tratava das armas de covardes (Plutarco, Moralia 224 B e 224 F). Provavelmente as recolhiam e as utilizavam para armar a seu próprio exército (Hunt 1997: 141), ainda que esta reutilização dos despojos de guerra não seja algo exclusivo dos espartanos (Kroll 1977: 144).

Desde o princípio distinguimos o troféu originário, o tronco vestido com as armas do vencido, do que temos chamado "permanente", construído geralmente de pedra.

Portanto, ainda que ambos os tipos de troféu simbolizem o mesmo, existe uma diferença fundamental; uns se construiriam para perdurar e perpetuar a vitória (e a guerra), ao mesmo tempo em que para ser admirados, enquanto os outros se levantariam para proclamar temporalmente a vitória.

Os tropaia construídos com armas eram uma forma de dedicação; uma panóplia inimiga, seguramente a melhor, oferecida à divindade, como preâmbulo do que depois se levaria ao santuário. Por outro lado, eram uma marca da vitória no momento em que esta se produz (Gabaldón Martínez 2005: 35).
Com a construção de monumentos permanentes o troféu originário não desaparece, ainda que cheguem um momento e lugar em que o sentido dele, como oferenda, passe a um segundo lugar, enquanto seu significado, como monumento comemorativo e expressão do poder, se coloque em um primeiro plano (Gabaldón Martínez 2005: 35-36).

\section{Conclusão}

O troféu era um manequim cruciforme, revestido de armas, de maneira a lhe dar aparência humana, não era um monumento comemorativo, no geral representava ou sugeria particularidades de uma vitória. Ele pode ser definido como o resultado de um ritual de armas. Era sagrado, se dedicava a uma divindade que estava presente na contenda e, de algum modo, era um receptáculo e representação da mesma (sobretudo Zeus Tropaios). Ele assinalava um espaço simbólico, porém real, como era o campo de batalha e fazia parte de um ritual de exposição, já que se erigia em lugares destacados para deixar constância da obtenção da vitória.

Nesses manequins residia um "sagrado" ou "temível”, ao qual toda sorte de precauções era necessária. O troféu era uma satisfação dada aos espíritos perversos ao mesmo tempo em que um meio mágico de os imobilizar.

Existia um valor mágico ao erigi-lo: ele imobiliza o espírito da batalha. Os troféus funerários serviam para fixar a alma do guerreiro no túmulo. Há outros casos em que ele fixa uma alma errante. Ele servia também para evocar um herói combatente. Erigi-lo purificava os vencedores e era um marco jurídico da vitória.

A construção do tropaion no campo de batalha e a oferenda dos despojos estavam ligadas à guerra hoplítica, concebida como um "sistema fechado" (Connor 1988: 24), que começava com a consulta ao oráculo e acabava com a vitória, levando as armas aos santuários. Quando as lutas hoplíticas entre as poleis deram andamento a lutas pela hegemonia da Hélade, muitas das normas e 
formalismos ritualizados começaram a mudar. Tal é o caso do troféu, que continuará sendo construído no campo de batalha, mas também será levado (sempre como símbolo da vitória) com um desejo de perpetuidade; algo similar ocorrerá com as grandes oferendas nos santuários. A dedicação das armas aos deuses era um ritual comum a todos os povos, ao passo que o troféu é próprio dos gregos.

Conforme expusemos, para compreender o troféu na Grécia Antiga, seu sentido original, sua evolução, consagração, suas formas de uso e sua função de preservar a memória, é indispensável considerá-lo em função da própria teologia da guerra.

PONTIN, P.B.V. The military trophies and the memory of war in ancient Greece. Revista do Museu de Arqueologia e Etnologia, São Paulo, 19: 221-233, 2009.

Abstract: This study aims to understand how the study of military trophies in Greece, since Archaic period, can redeem the presence of a military rite designed to perpetuate the memory of a battle besides, fix and control certain apotropaic energies.

Keywords: Military Trophies - Greek Warfare - War equipment - Ancient Greece.

\section{Referências bibliográficas}

BOWDEN, H.

1990 Herodotos and Greek Sanctuaries. Tese de Doutorado. Universidade de Oxford.

BURKERT, W.

1993 Religião Grega na Época Clássica e Arcaica. Lisboa: Fund. Calouste Gubenkian. (Versão em inglês, Greek religion. Archaic and Classical. Londres, John Wiley Trade 1985).

BEAZLEY, J.D.; CASKEY, L.D.

1963[1931] Attic Vase Paintings in the Museum of Fine Arts. Oxford, Boston: Oxford University Press, 3 vols.

CHANIOTIS, A.

2005 War in the Hellenistic world: a social and cultural history. United Kingdom: Blackwell. COOK, A.B.

1965 Zeus. A study in ancient religion. II. Zeus god of the dark sky (thunder and lightning). N. York: Cambridge University Press. 2 vols.

CONNOR, W.R.

1988 Early Greek Land Warfare as Symbolic Expression”. P $\mathcal{E}$ P, 119: 3-8. (Versão em francês, em Brulé, P.; Oulhen, J. 1999: 289-314).

CONTI, G.

2001 Da albero-trofeo a trofeo-croce. Rendiconti della Pontifícia Accademia Romana di Archeologia, 71 (série III): 273-326.

DÉTIENNE, M.

1968 La Phalange: Problèmes et Controverses". In: Vernant, J.-P. (Ed.) Problèmes de la Guerre en Grèce Ancienne. Paris, La Hayle: 119-142.

\section{DIODORO DA SICÍLIA}

1976 The Library of History of Diodorus of Sicily. Trad. C.H. Oldfather. Londres: Harvard University Press.

DUCREY, P.

1985 Guerre et Guerriers dans la Grèce Antique. Paris: Payot.

ÉSQUILO

2003 Os Sete contra Tebas. Trad. Donaldo Schüler. Porto Alegre: L\&PM.

FERNÁNDEZ NIETO, F.J.

1975 Los acuerdos bélicos en la antigua Grecia. T. I. Texto. Santiago de Compostela. 
FINLEY, M.

1986 El mundo de Odiseu. México: FCE.

GABALDÓN MARTÍNEZ, M. del M.

2005 Rituales de armas y de victoria: Lugares de culto y armamento en el mundo griego. BAR International Series 1354.

1997 El trofeo griego. Ritual de armas y símbolo de la victoria. Boletín de la Asociación Española de Amigos de la Arqueologia, 41: 93-110.

GANSINIEC, Z.

1955 Geneza Tropaionu. Biblioteka Archeologiczna, 5. Varsóvia/ Wroclaw. Com resumo em francês: 133-145.

HANSON, V.D.

1989 The Western Way of War. Infantry Battle in Classical Greece. N. York, Londres: OUP.

HERÓDOTO

1989 Los nueve libros de la Historia. Int. de V. de Lama de la Cruz. Madri: Edaf.

HUNT, P.

1997 Helots at the Battle of Pataea. Historia, 46 (2): 129-144.

JANSSEN, A.J.

1957 Het antieke Tropaion. Ledeberg: Gent.

KRENTZ, P.

2002 Fighting by the Rules, The Invention of the Hoplite Agôn. Hesperia, 71: 23-39.

KROLL, J.H.

1977 Some Athenian armor tokens. Hesperia, 46: 141-146.

KURTZ, D.C.; BOARDMAN, J.

1971 Greek burial customs. Londres: Thames \& Hudson.

LAUNEY, M.

1987 Recherches sur les Armées Hellenistiques II. Reimpressão com adenda de Y. Garlan, P. Gauthier e C. Orrieux. Paris: De Boccard.

LONIS, R.

1985 La Guerre en Grèce. Quinze Années de Recherche: 1968-1983". REG, 98: 321-379.

1979 Guerre et Religion en Grèce à L'Époque Classique. Paris: Annales Littéraires de L'Université de Besançon, 238.

NILSSON, M.P.

1950 The Minoan-Mycenaean Religion and its survival in Greek Religion. Lund: Gleerup.

1967 A History of Greeek Religion. Oxford: PAUSÂNIAS Clarendon Press.

1992 Description de la Grèce. Trad. Jean Pouilloux. Paris: Les Belles Lettres.
PICARD, G.-C.

1957 Les Trophées Romains. Paris: BEFAR, 187. De Boccard.

\section{PLUTARCO}

1969 Moralia. Tradução de H. North Fowler. Londres, Cambridge, Mass: The Loeb Classical Library.

1969 Lives. Tradução de B. Perrin. Londres, Cambridge, Mass: The Loeb Classical Library. 11 vols.

POLIGNAC, F. DE

1984 La naissance de la cité grecque. Paris: La Decouverte.

1995 Cults, territory and the origins of the Greek City-State. Chicago, Londres: University of Chicago Press. (Tradução e revisão de 1984).

PONTIN, P.B.V.

2006 O escudo grego: a simbologia de um equipamento defensivo. Tese (Doutorado). Museu de Arqueologia e Etnologia da Universidade de São Paulo. São Paulo.

PRITCHETT, W.K.

1971 Ancient Greek Military Practices. Berkeley: University of California Publications.

1991 [1971]The Greek State at War, I-V, Berkeley, Los Angeles, Londres: University of California Publications.

PROPÉRCIO

1963 Elegías. Barcelona: Ed. De A. Tovar e M. T. Belfiore.

REINACH, A.J.

1913 Les trophées et les origines religieuses de la guerre. Revue Internationale d'Etnographie et de Sociologie, 4: 211-237.

ROMILLY, J.

1968 Guerre et Paix entre Cités. In: Vernant, J.-P. (Ed.) Problèmes de la Guerre en Grèce Ancienne. Paris, La Haye: 207-220 .

SAGE, M.

1996 Warfare in Ancient Greece. A Sourcebook. Londres: Routledge.

SALCEDO, G.F.

1983 Los relieves de armas del teatro de Merida. Lucentum, II: 243-283.

SEGARRA, C.D.

1997 La alteridad ritualizada en la oferenda. Habis, 28: 275-298.

SÓFOCLES

1996 As Traquinias. Trad. De Maria do Céu Zambujo Fialho. Brasília: Editora Universidade de Brasília.

TOUCHETTE, L.A.

1998 Two Nikai with trophy-two woman with a Herm: public and private in Roman 
copies of the Nike parepet. In: Cima, M.; La Roca, E. (Eds.) Horti Romani. Atti del Convegno Internazionale. Roma, 1995. Roma, L'Erma di Bretschneider: 315-331.

TUCÍDIDES

1987 História da Guerra do Peloponeso. Trad. M. da G. Kury. Brasília: Editora Universidade de Brasília.

VAN WEES, $\mathrm{H}$.

1996 Heroes, Knights and Nutters. Lloyd,
W.A.B. (Ed.) Battle in Antiquity. Londres, Classical Press of Wales: 1-86.

WEST III, W.C.

1969 The trophies of the Persian Wars. Classical Philology, 64: 7-19.

\section{WOELCKE, K.}

1911 Beiträge zur Geschichte des Tropaions. Bjb, 120: 127-235.

ZANKER, P.

1992 Augusto y el poder de las imágenes. Madri: Alianza Editorial. 